\title{
INTEGRASI METODE IPA DAN MODEL KANO DALAM PENGEMBANGAN KUALITAS PELAYANAN PERPUSTAKAAN
}

\author{
Anita Indrasari \\ Program Studi S1 Teknik Industri, Universitas Setia Budi \\ email: anita.indrasari@gmail.com
}

\begin{abstract}
ABSTRAK
Perpustakaan memegang peran penting dalam proses pembelajaran di perguruan tinggi. Perpustakaan dituntut untuk terus meningkatkan kualitas pelayanannya dan mampu mengakomodasi berbagai kebutuhan penggunanya yang selalu meningkat. Penelitian ini menggunakan model integrasi IPA-Kano untuk mengukur kondisi kinerja pelayanan perpustakaan sekaligus mengidentifikasi atribut-atribut pelayanan yang harus diprioritaskan demi pengembangan kualitas pelayanan perpustakaan. Variabel penelitian yang digunakan mengadopsi dimensi yang ada pada LibQual+TM dan diturunkan menjadi 26 indikator/atribut pelayanan. Data dikumpulkan dari kuesioner yang disebar secara acak pada 100 orang pengunjung perpustakaan. Dari hasil pengolahan data menggunakan IPA-Kano model, diperoleh atribut pelayanan di perpustakaan USB yang perlu mendapat prioritas utama untuk ditingkatkan yaitu atribut: AI1(Kelengkapan koleksi buku), AI3(Kelengkapan koleksi jurnal dan majalah), AI8 (Kemudahan akses internet di perpustakaan), PC3 (Penataan buku di rak yang memudahkan pengguna dalam mencari materi), AI2 (Kelengkapan koleksi karya ilmiah).
\end{abstract}

Kata Kunci: IPA, Kano, LibQual+TM, kualitas, perpustakaan

\begin{abstract}
Libraries have an important role in the learning process in higher education. Libraries required to continuously improve the quality of service and had to be able to accommodate the various needs of users that always increase. This study uses a model of integration of IPA-Kano to measure the condition of library service performance as well as identifying the attributes of service that should be prioritized for the development of library service quality. Variables used in this research adopt from the dimensions that exist in LibQual + TM and breakdown to 26 indicator/service attributes. Data were collected from questionnaires randomly distributed to the 100 library visitors. From the results of data processing using IPA-Kano model, the USB library service attributes that need to be improved is the main priority attributes: AI1 (Completeness of books), AI3 (Completeness collection of journals and magazines), AI8 (Ease of internet access in the library), PC3 (Structuring the book on the shelf that allows users to search for material), AI2 (completeness collection of scientific papers).
\end{abstract}

Keywords: IPA, Kano, LibQual+TM, quality, library

\section{PENDAHULUAN}

Perpustakaan memegang peran penting dalam proses pembelajaran di perguruan tinggi. Perpustakaan menjadi pusat pelayanan informasi penunjang pembelajaran dan tri darma perguruan tinggi, yaitu: pendidikan, penelitian dan pengabdian masyarakat. Melihat perkembangan teknologi yang semakin pesat saat ini, perpustakaan dituntut untuk terus mengembangkan pelayanannya. Perpustakaan bukan hanya sebagai penyedia buku text kuliah dan ruang baca. Perpustakaan harus mampu mengakomodasi berbagai kebutuhan pengguna yang semakin meningkat seiring dengan meningkatnya kemajuan jaman.

Pengembangan dan peningkatan kualitas pelayanan dapat dilakukan ketika kondisi kinerja saat ini diketahui. Identifikasi atribut pelayanan yang benar-benar meningkatkan kepuasan pengguna juga perlu dilakukan sebagai dasar prioritas dalam pengembangan kualitas perpustakaan.

\section{TINJAUAN PUSTAKA}

Integrasi antara model Importance and Performance Analysis (IPA) dan Kano telah banyak digunakan dalam penelitian mengenai kualitas. Wu, dkk. [1] menggunakan integrasi kedua model tersebut untuk mengidentifikasi key success factor (KSFs) dengan mengambil studi kasus pada E-Life Mall Corporation. Sihombing, dkk. [2] mengukur kepuasan pelanggan dengan menggunakan Kano Model dan IPA dengan menggunakan atribut Servqual. 
Kuo [3] dalam penelitiannya mengajukan IPAKano Model sebagai alat untuk mengkategorisasi dan mendiagnosa service quality attribute dan menyusun strategi spesifik untuk masing-masing atribut di tiap-tiap kategori. Model integrasi ini dapat dilihat pada Gambar 1.

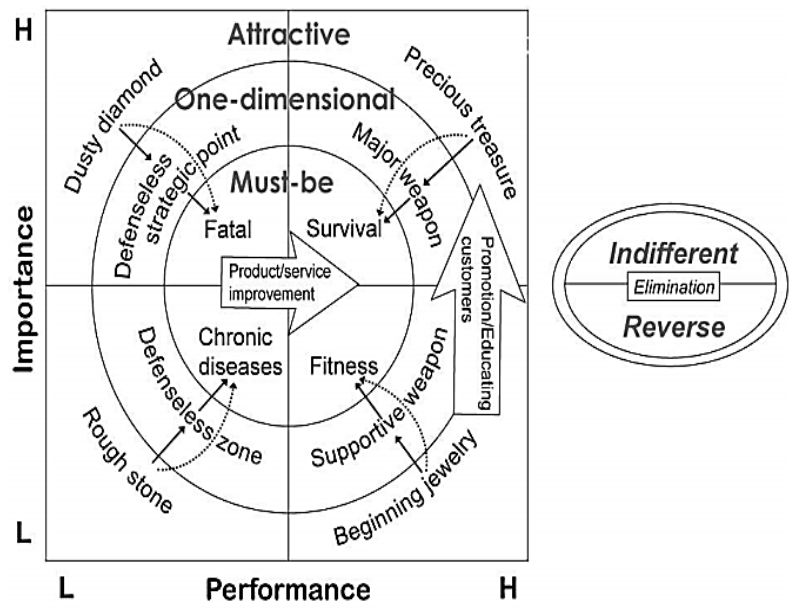

Gambar 1. Model Integrasi IPA-Kano [1]

Model ini merumuskan prioritas strategi pengembangan tiap-tiap atribut pelayanan perpustakaan. Prioritas pengembangan diperoleh dengan cara mengkombinasikan hasil klasifikasi matriks IPA dan klasifikasi model Kano dari setiap atribut pelayanan dan mengkasifikasikannya ke dalam 12 kategori dengan tingkat prioritas masing-masing seperti terlihat pada Tabel 1.

Penelitian ini menggunakan model integrasi IPA-Kano menurut Kuo [3] untuk mengukur kondisi kinerja pelayanan perpustakaan sekaligus mengidentifikasi atribut-atribut pelayanan yang harus diprioritaskan pengembangannya demi kepuasan pengguna.

\section{METODE PENELITIAN}

Langkah-langkah penelitian ini dapat dilihat pada Gambar 2. Penelitian ini menggunakan variable penelitian yang diadopsi dari metode LibQual+TM. Metode LibQual+TM menggunakan prinsip bahwa hanya pengguna jasa yang berhak menilai kualitas layanan, seluruh penilaian lain pada dasarnya tidaklah relevan. Dimensi pelayanan perpustakaan dalam LibQual+TM terdiri dari 4 dimensi yaitu: (1) Sikap Petugas dalam Melayani (Affect of Service), (2) Akses terhadap Informasi (Access to Information), 3) Kemudahan Pengguna dalam Pencarian Informasi tanpa Bantuan Petugas (Personal Control), 4) Perpustakaan sebagai Sebuah Tempat (Library as a Place).

Dari keempat variable/dimensi tersebut diturunkan lagi menjadi 26 atribut, yaitu: berpenampilan rapi dan sopan (AS-1), perhatian kepada para pengguna perpustakaan (AS-2), ramah dan sopan dalam melayani (AS-3), cepat, tanggap dan berinisiatif membantu pengguna yang memerlukan bantuan (AS-4), punya pemahaman dan ketrampilan yang cukup untuk menjawab pertanyaan dan menyelesaikan masalah yang dihadapi pengguna (AS-5), mengerti akan kebutuhan pengguna (AS-6),

Tabel 1. Series, Categories dan Strategic Priorities IPA-KANO Model

\begin{tabular}{|c|c|c|c|c|c|c|}
\hline \multirow{2}{*}{ Series } & \multirow{2}{*}{\multicolumn{2}{|c|}{ Categories }} & \multirow{2}{*}{ Importance } & \multirow{2}{*}{ Performance } & \multicolumn{2}{|c|}{ Strategic Priorities } \\
\hline & & & & & Improvement & Keep up the good work \\
\hline \multirow{4}{*}{ Hygiene } & 1 & Survival & High & High & - & 1 \\
\hline & 2 & Fatal & High & Low & 1 & - \\
\hline & 3 & Chronic disease & Low & Low & 2 & - \\
\hline & 4 & Fitness & Low & High & - & 2 \\
\hline \multirow{4}{*}{ War } & 5 & Major Weapon & High & High & - & 3 \\
\hline & 6 & Defenseless Strategy point & High & Low & 3 & - \\
\hline & 7 & Defenseless zone & Low & Low & 4 & - \\
\hline & 8 & Supportive weapon & Low & High & - & 4 \\
\hline \multirow{4}{*}{ Treasure } & 9 & Precious treasure & High & High & - & 5 \\
\hline & 10 & Dusty diamond & High & Low & 5 & - \\
\hline & 11 & Rough stone & Low & Low & 6 & - \\
\hline & 12 & Beginning Jewelry & Low & High & - & 6 \\
\hline
\end{tabular}


kelengkapan koleksi buku (AI-1), kelengkapan koleksi karya ilmiah (AI-2), kelengkapan koleksi jurnal dan majalah (AI-3), kelengkapan koleksi surat kabar (AI-4), kelengkapan koleksi digital (AI-5), kemutakhiran koleksi(AI-6), relevansi koleksi dengan yang dibutuhkan pengguna (AI-7), kemudahan akses internet di perpustakaan(AI-8), kemudahan akses koleksi digital (AI-9), kemudahan akses materi/koleksi milik perpustakaan lain (AI-10), kemudahan akses digilib Universitas Setia Budi (USB) dari rumah dan tempat lain (AI-11), Digilib USB dan catalog online yang mudah digunakan (PC1), petunjuk dan panduan yang jelas mengenai penggunaan fasilitas perpustakaan secara mandiri (PC-2), penataan buku di rak yang memudahkan pengguna dalam mencari materi (PC-3), nyaman dan menarik untuk dikunjungi (LP-1), ketersediaan fasilitas fisik (LP-2), tempat yang tenang untuk aktivitas belajar individu (LP-3), tempat yang cocok untuk belajar kelompok (LP-4), tempat yang memberi inspirasi untuk membaca dan belajar (LP-5), desain ruangan yang menarik dan ergonomis (LP-6).

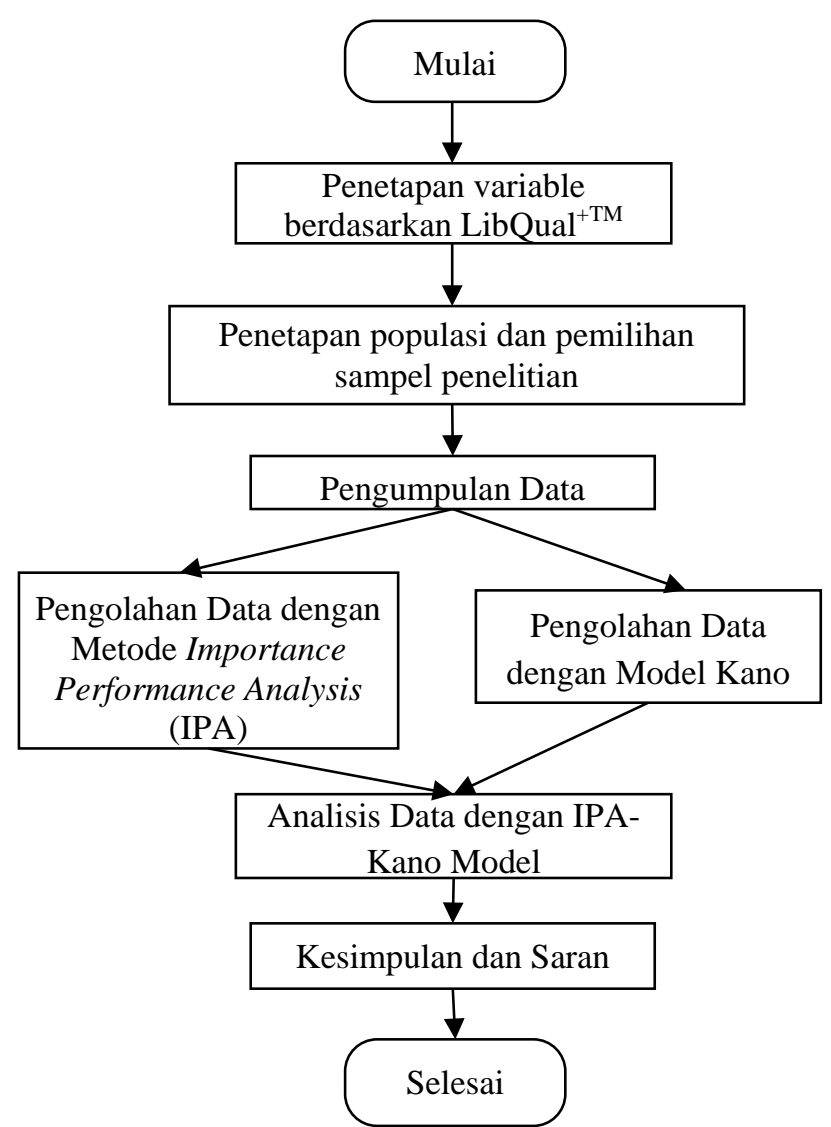

Gambar 2. Langkah-langkah Penelitian
Pengumpulan data dilakukan dengan penyebaran kuesioner. Jumlah sampel yang diambil adalah sebanyak 100 orang responden/ pengunjung perpustakaan. Kuesioner terbagi menjadi 2 bagian sesuai cara pengolahannya, yaitu bagian pertama kuesioner IPA dan bagian kedua kuesioner Kano. Dalam masing-masing bagian kuesioner terdapat 26 pernyataan yang mewakili setiap indikator LibQual+TM.

Rekap data kuesioner bagian pertama diolah dengan metode IPA dan diperoleh diagram IPA pelayanan perpustakaan USB. Rekap data kuesioner kedua diolah dengan model Kano sehingga diperoleh klasifikasi atribut pelayanan perpustakaan berdasar model Kano. Kedua hasil olahan data tersebut kemudian digabungkan dalam model intergasi IPA-Kano untuk disusun strategi pengembangannya.

\section{HASIL DAN PEMBAHASAN}

Data penelitian evaluasi kualitas pelayanan perpustakaan USB ini diambil dengan sampling acak sederhana dengan menggunakan kuesioner yang dibagi kepada 100 orang pengunjung perpustakaan USB.

Sebelum dilakukan pengolahan data, uji validitas dan reabilitas dilakukan. Dari 26 atribut yang dijabarkan menjadi 52 item pertanyaan, diperoleh bahwa seluruh item valid dan reliabel, dengan nilai reabilitas sebesar 0,91 .

\section{Karakteristik Responden dan Tingkat Kepuasan Secara Umum}

Dari kuesioner yang terkumpul, dapat diketahui bahwa pengunjung perpustakaan USB masih didominasi oleh mahasiswa (97\%), dan dari kalangan internal sendiri. Kepentingan meminjam dan mengembalikan buku masih menjadi alasan terbesar para mahasiswa mengunjungi perpustakaan. Disusul dengan kepentingan untuk mengakses internet, membaca dan belajar, dan lainnya. Frekuensi kunjungan pengguna ke perpustakaan realtif merata, antara 1-4 x per bulan, 5-8x per bulan dan lebih dari $8 \mathrm{x}$ per bulan. Dari hasil kuesioner juga diperoleh tingkat kepuasan pengguna secara umum seperti Gambar 3. 


\section{Tingkat Kepuasan Pengguna Perpustakaan USB Tahun}

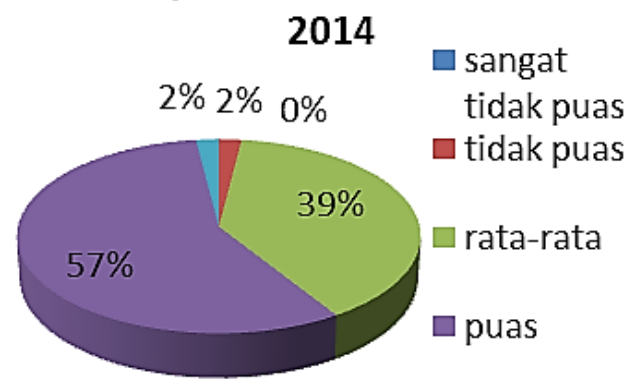

$\square$ sangat puas

Gambar 3. Tingkat Kepuasan Pengguna Perpustakaan Secara Umum

Mayoritas pengguna (57\%) menyatakan puas dengan pelayanan perpustakaan USB, dan selebihnya berpendapat rata-rata dan tidak puas. Nilai kepuasan pengguna secara umum sebesar 3,59 dengan skala 5. Melihat hasil ini maka dapat dikatakan bahwa perpustakaan USB masih perlu meningkatkan kualitas pelayanan, sehingga tingkat kepuasan pengguna perpustakaan akan lebih meningkat lagi.

\section{Metode Importance Performance Analysis (IPA)}

IPA dilakukan dengan menghitung nilai rata-rata tingkat kinerja (performance) dan tingkat harapan yang sebenarnya (importance) dari masing-masing atribut. Dari nilai rata-rata masing-masing atribut tersebut kemudian dihitung nilai rata-rata global masing-masing untuk performance dan importance, yang nantinya akan menjadi garis pemisah dalam matriks IPA. Dari perhitungan, diperoleh nilai rata-rata masing-masing atribut seperti terlihat pada Tabel 2.

Dari hasil rata-rata nilai masing-masing atribut untuk kinerja (performance) dan harapan sebenarnya (importance), dapat digambarkan pada sebuah matriks Important and Performance Analysis seperti pada Gambar 4. Dari hasil analisis, terdapat 9 atribut pelayanan yang berada dalam kuadran pertama, yaitu atribut dengan tingkat importance dan performance yang sama-sama tinggi sebagai berikut: Kelengkapan koleksi: surat kabar (AI4), Kelengkapan koleksi : karya ilmiah (AI2), Nyaman dan menarik untuk dikunjungi
(LP1), Ketersediaan fasilitas fisik (LP2), Tempat yang tenang untuk aktivitas belajar individu (LP3), Tempat yang cocok untuk belajar kelompok (LP4), Tempat yang memberi inspirasi untuk membaca dan belajar (LP5), Desain ruangan yang menarik dan ergonomis (LP6), Berpenampilan rapi dan sopan (AS1).

Tabel 2. Nilai Rata-Rata Tingkat Performace dan Importance

\begin{tabular}{ccccc}
\hline No & Dimensi & Atribut & Performance & Importance \\
\hline 1 & Affect & AS1 & 3.65 & 4.31 \\
2 & of & AS2 & 3.38 & 4.10 \\
3 & Service & AS3 & 3.51 & 4.28 \\
4 & & AS4 & 3.32 & 4.26 \\
5 & & AS5 & 3.29 & 4.14 \\
6 & & AS6 & 3.24 & 4.21 \\
\hline 7 & Access & AI1 & 2.96 & 4.50 \\
8 & to & AI2 & 3.29 & 4.51 \\
9 & Inform & AI3 & 2.91 & 4.34 \\
10 & ation & AI4 & 3.30 & 4.32 \\
11 & & AI5 & 2.92 & 4.19 \\
12 & & AI6 & 3.03 & 4.25 \\
13 & & AI7 & 3.10 & 4.22 \\
14 & & AI8 & 3.14 & 4.39 \\
15 & & AI9 & 2.96 & 4.14 \\
16 & & AI10 & 2.82 & 4.17 \\
17 & & AI11 & 3.00 & 4.11 \\
\hline 18 & Person & PC1 & 3.11 & 4.24 \\
19 & al & PC2 & 3.17 & 4.24 \\
20 & Control & PC3 & 3.01 & 4.39 \\
\hline 21 & Library & LP1 & 3.62 & 4.46 \\
22 & as a & LP2 & 3.80 & 4.52 \\
23 & Place & LP3 & 3.33 & 4.50 \\
24 & & LP4 & 3.56 & 4.40 \\
25 & & LP5 & 3.51 & 4.47 \\
26 & & LP6 & 3.31 & 4.39 \\
\hline & Rata-rata & & 3.24 & 4.31 \\
\hline
\end{tabular}

Atribut pelayanan yang berada pada kuadran II diagram IPA dengan tingkat importance tinggi dan performance.nya masih rendah adalah sebagai berikut: Kelengkapan koleksi: buku (AI1), Kelengkapan koleksi: jurnal dan majalah (AI3), Kemudahan akses internet di perpustakaan (AI8), Penataan buku di rak yang memudahkan pengguna dalam mencari materi (PC3).

Atribut pelayanan dengan tingkat importance dan tingkat performance yang sama-sama rendah (kuadran III) adalah sebgai berikut: Kemutakhiran koleksi (AI6), Relevansi Koleksi dengan yang dibutuhkan pengguna (AI7), Kemudahan akses koleksi digital (AI9), 
Kemudahan akses materi/koleksi milik perpustakaan lain (AI10), Kemudahan akses Digilib USB dari rumah dan tempat lain (AI11), Digilib USB dan catalog online yang mudah digunakan (PC1), Petunjuk dan panduan yang jelas mengenai penggunaan fasilitas perpustakaan secara mandiri (PC2), Kelengkapan koleksi: digital (AI5), Mengerti akan kebutuhan pengguna (AS6).

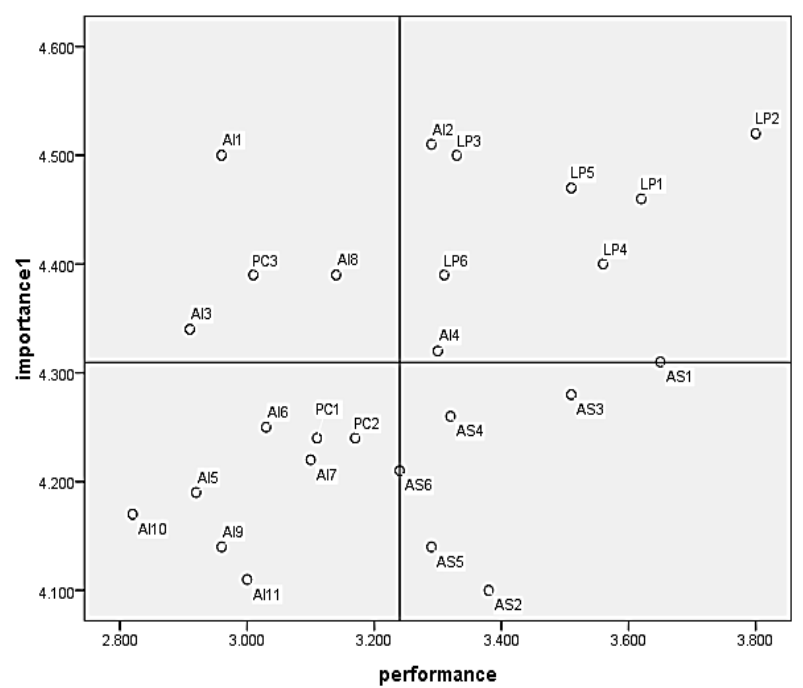

Gambar 4. Diagram Importance Performance Analysis Pelayanan Perpustakaan USB

Atribut pelayanan yang berada pada kuadran IV diagram IPA yaitu atribut pelayanan dengan tingkat performance tinggi, sedangkan tingkat importance.nya rendah adalah: Punya pemahaman dan ketrampilan yang cukup untuk menjawab pertanyaan dan menyelesaikan masalah yang dihadapi pengguna (AS5), Perhatian kepada para pengguna perpustakaan (AS2), Ramah dan sopan dalam melayani (AS3), Cepat, tanggap dan berinisiatif membantu pengguna yang memerlukan bantuan (AS4) dan atribut mengerti akan kebutuhan pengguna (AS6). Untuk atribut pelayanan mengerti akan kebutuhan pengguna (AS6) berada pada garis batas antara kuadran III dan IV, sehingga bisa masuk ke dalam dua kategori, yaitu low priority maupun possible overkill.

\section{Analisis Model Kano}

Pada pengumpulan data dengan kuesioner Kano, dalam satu atribut terdapat 2 item pernyataan, yaitu pernyataan fungsional dan pernyataan disfungsional. Pernyataan fungsional adalah gambaran ketika suatu atribut pelayanan terpenuhi, dan sebaliknya, pernyataan disfungsional adalah gambaran ketika suatu atribut pelayanan tidak terpenuhi oleh penyedia layanan dalam hal ini perpustakaan USB.

Pada setiap item pernyataan, responden disediakan 5 skala penilaian untuk dipilih, yaitu: tidak suka/dislike (TS), toleran/live with $(\mathrm{T})$, netral/neutral $(\mathrm{N})$, sudah seharusnya/must be $(\mathrm{SH})$, dan suka/like (S). Dari kombinasi respon responden pada setiap item dapat ditentukan kategori atribut pelayanan tersebut sesuai model Kano, dengan mengikuti Kano Evaluation Tabel seperti terlihat Tabel 3.

Tabel 3. Evaluasi Kano

\begin{tabular}{|c|c|c|c|c|c|}
\hline \multirow[b]{2}{*}{$\begin{array}{c}\text { Customer } \\
\text { Requirement }\end{array}$} & \multicolumn{5}{|c|}{ Dysfunctional } \\
\hline & Like & $\begin{array}{c}\text { Must- } \\
\text { be }\end{array}$ & Neutral & $\begin{array}{l}\text { Live } \\
\text { With }\end{array}$ & Dislike \\
\hline Like & $\mathrm{Q}$ & A & A & A & $\mathrm{O}$ \\
\hline ฮ Must-be & $\mathrm{R}$ & I & I & I & M \\
\hline Neutral & $\mathrm{R}$ & I & I & I & M \\
\hline$\Xi$ Live with & $\mathrm{R}$ & I & I & I & M \\
\hline I Dislike & $\mathrm{R}$ & $\mathrm{R}$ & $\mathrm{R}$ & $\mathrm{R}$ & $\mathrm{Q}$ \\
\hline
\end{tabular}

Keterangan:

$$
\begin{array}{ll}
\mathrm{Q} & : \text { Quesionable } \\
\mathrm{A} & : \text { Attractive } \\
\mathrm{I} & : \text { Indifferent } \\
\mathrm{R} & : \text { Reverse } \\
\mathrm{M} & : \text { Must be } \\
\mathrm{O} & : \text { One Dimensional }
\end{array}
$$

Setelah respon masing-masing responden dikategorikan menjadi $\mathrm{A}, \mathrm{O}, \mathrm{M}, \mathrm{I}, \mathrm{R}$ atau $\mathrm{Q}$, kemudian jumlah masing-masing kategori pada tiap-tiap atribut pelayanan dihitung. Dan kategori Kano untuk masing-masing atribut ditentukan dengan aturan sebagai berikut: Jika $(\mathrm{O}+\mathrm{A}+\mathrm{M})>(\mathrm{I}+\mathrm{R})$, maka kategori atribut pelayanan tersebut adalah max $(\mathrm{O}, \mathrm{A}, \mathrm{M})$; dan jika tidak, maka kategori Kano untuk atribut pelayanan tersebut adalah max (I, R). Hasil rekap penghitungan dan pengkategori-sasian Kano dapat dilihat pada Tabel 4.

Dari 26 atribut pelayanan yang diteliti, terdapat 3 atribut pelayanan yang termasuk dalam kategori Indifferent, yaitu atribut pelayanan yang ketika terpenuhi maupun tidak, tidak mempengaruhi tingkat kepuasan pelanggan. Atribut pelayanan yang termasuk di dalamnya adalah: Punya pemahaman dan 
ketrampilan yang cukup untuk menjawab pertanyaan dan menyelesaikan masalah yang dihadapi pengguna (AS5), Kelengkapan koleksi: surat kabar (AI4), dan kelengkapan koleksi : digital (AI5).

Tabel 4. Rekapan Hasil Evaluasi Kano

\begin{tabular}{|c|c|c|c|c|c|c|c|c|c|}
\hline Dimensi & A & $\mathrm{O}$ & M & I & $\mathrm{R}$ & Q & $\begin{array}{c}\mathrm{O}+\mathrm{A} \\
+\mathrm{M}\end{array}$ & $\mathrm{I}+\mathrm{R}$ & $\begin{array}{c}\text { Kategori } \\
\text { Kano }\end{array}$ \\
\hline AS1 & 3 & 16 & 48 & 32 & 0 & 1 & 67 & 32 & $\mathrm{M}$ \\
\hline AS2 & 3 & 8 & 49 & 39 & 1 & 0 & 60 & 40 & M \\
\hline AS3 & 6 & 16 & 50 & 27 & 1 & 0 & 72 & 28 & M \\
\hline AS4 & 4 & 13 & 41 & 42 & 0 & 0 & 58 & 42 & M \\
\hline AS5 & 6 & 7 & 36 & 51 & 0 & 0 & 49 & 51 & I \\
\hline AS6 & 10 & 10 & 34 & 46 & 0 & 0 & 54 & 46 & M \\
\hline AI1 & 4 & 10 & 48 & 34 & 3 & 1 & 62 & 37 & M \\
\hline AI2 & 2 & 21 & 42 & 34 & 1 & 0 & 65 & 35 & M \\
\hline AI3 & 8 & 15 & 40 & 36 & 1 & 0 & 63 & 37 & M \\
\hline AI4 & 9 & 10 & 26 & 55 & 0 & 0 & 45 & 55 & I \\
\hline AI5 & 4 & 15 & 28 & 51 & 2 & 0 & 47 & 53 & I \\
\hline AI6 & 5 & 14 & 34 & 46 & 1 & 0 & 53 & 47 & M \\
\hline AI7 & 2 & 12 & 43 & 42 & 1 & 0 & 57 & 43 & M \\
\hline AI8 & 3 & 22 & 39 & 34 & 1 & 1 & 64 & 35 & M \\
\hline AI9 & 4 & 13 & 39 & 42 & 0 & 2 & 56 & 42 & M \\
\hline AI10 & 5 & 14 & 34 & 45 & 1 & 1 & 53 & 46 & M \\
\hline AI11 & 6 & 17 & 29 & 48 & 0 & 0 & 52 & 48 & M \\
\hline PC1 & 6 & 15 & 34 & 44 & 0 & 1 & 55 & 44 & M \\
\hline PC2 & 6 & 13 & 34 & 47 & 0 & 0 & 53 & 47 & M \\
\hline PC3 & 5 & 18 & 42 & 33 & 2 & 0 & 65 & 35 & M \\
\hline LP1 & 9 & 27 & 34 & 28 & 1 & 1 & 70 & 29 & $\mathrm{M}$ \\
\hline LP2 & 11 & 30 & 32 & 26 & 1 & 0 & 73 & 27 & M \\
\hline LP3 & 11 & 15 & 41 & 32 & 0 & 1 & 67 & 32 & M \\
\hline LP4 & 12 & 18 & 33 & 35 & 1 & 1 & 63 & 36 & M \\
\hline LP5 & 11 & 14 & 37 & 37 & 0 & 1 & 62 & 37 & M \\
\hline LP6 & 10 & 16 & 36 & 37 & 0 & 1 & 62 & 37 & M \\
\hline
\end{tabular}

Sedangkan 23 atribut lainnya termasuk dalam kategori Must Be, yaitu kategori atribut pelayanan dimana ketika hal tersebut tidak dipenuhi maka akan menurunkan tingkat kepuasan pengguna, namun jika kebutuhan pelayanan tersebut dipenuhi tidak menaikkan kepuasan pengguna secara signifikan, karena pengguna merasa bahwa atribut pelayanan tersebut memang sudah seharusnya terpenuhi.

\section{Integrasi Metode Importance Performance Analysis (IPA) dan Kano}

Setelah hasil klasifikasi atribut pelayanan menurut IPA dan menurut model Kano telah diperoleh, kemudian diklasifikasikan berdasarkan IPA-Kano model [1] sepeti terlihat pada Tabel 5.

Kategori model IPA-Kano yang pertama yaitu survival. Kategori ini digunakan untuk atribut dengan high performance, high importance dan termasuk kategori must be. Atribut pelayanan yang masuk dalam kategori ini harus terus dijaga agar tingkat performansinya tidak menurun, karena jika tingkat performansinya menurun maka ketidak puasan pelanggan akan langsung terjadi. Berdasarkan hasil analisis, diperoleh 7 atribut yang masuk dalam kategori survival, yaitu: LP1(Nyaman dan menarik untuk dikunjungi), LP2 (Ketersediaan fasilitas fisik), LP3 (Tempat yang tenang untuk aktivitas belajar individu), LP4 (Tempat yang cocok untuk belajar kelompok), LP5 (Tempat yang memberi inspirasi untuk membaca dan belajar), LP6 (Desain ruangan yang menarik dan ergonomis) dan AS1 (Berpenampilan rapi dan sopan).

Kategori yang kedua yaitu fatal. Kategori ini dimaksudkan untuk jenis atribut pelayanan dengan low performance, high importance dan masuk kategori must be. Atribut pelayanan yang berada pada kategori ini harus segera diperbaiki dan ditingkatkan kinerjanya, sehingga tidak berakibat menurunnya kepuasan pengguna secara fatal. Terdapat 5 atribut yang masuk dalam kategori fatal, yaitu: AI1 (Kelengkapan koleksi: buku), AI3 (Kelengkapan koleksi: jurnal dan majalah), AI8 (Kemudahan akses internet di perpustakaan), PC3 (Penataan buku di rak yang memudahkan pengguna dalam mencari materi), AI2 (Kelengkapan koleksi: karya ilmiah).

Chronic desease, merupakan kategori yang digunakan untuk atribut pelayanan dengan low performance, low importance dan masuk kategori must be. Atribut yang masuk dalam kategori ini seharusnya segera ditingkatkan dengan prioritas kedua setelah atribut pelayanan dengan kategori fatal diperbaiki kinerjanya. Dari hasil analisis, terdapat 8 atribut pelayanan yang masuk kategori chronic desease, yaitu: AI6 (Kemutakhiran koleksi), AI7 (Relevansi Koleksi dengan yang dibutuhkan pengguna), AI9 (Kemudahan akses koleksi digital), AI10 (Kemudahan akses materi/koleksi milik perpustakaan lain), AI11 (Kemudahan akses Digilib USB dari rumah dan tempat lain), PC1 (Digilib USB dan catalog online yang mudah digunakan), PC2 (Petunjuk dan panduan yang 
Tabel 5. Klasifikasi IPA-Kano Model

\begin{tabular}{llcl}
\hline Atribut & Hasil IPA & Hasil Kano & IPA-Kano \\
\hline LP1 & Keep up the good work (I) & M & Survival \\
\hline LP2 & Keep up the good work (I) & M & Survival \\
\hline LP3 & Keep up the good work (I) & M & Survival \\
\hline LP4 & Keep up the good work (I) & M & Survival \\
\hline LP5 & Keep up the good work (I) & M & Survival \\
\hline LP6 & Keep up the good work (I) & M & Survival \\
\hline AS1 & Keep up the good work (I) & M & Survival \\
\hline AI1 & Concentrate here (II) & M & Fatal \\
\hline AI3 & Concentrate here (II) & M & Fatal \\
\hline AI8 & Concentrate here (II) & M & Fatal \\
\hline PC3 & Concentrate here (II) & M & Fatal \\
\hline AI2 & Keep up the good work (I) & M & Fatal \\
\hline AI6 & Low priority (III) & M & Chronic diseases \\
\hline AI7 & Low priority (III) & M & Chronic diseases \\
\hline AI9 & Low priority (III) & M & Chronic diseases \\
\hline AI10 & Low priority (III) & M & Chronic diseases \\
\hline AI11 & Low priority (III) & M & Chronic diseases \\
\hline PC1 & Low priority (III) & M & Chronic diseases \\
\hline PC2 & Low priority (III) & M & Chronic diseases \\
\hline AS6 & Low priority (III) / possible overkill (IV) & M & Chronic diseases/Fitness \\
\hline AS2 & Possible overkill (IV) & M & fitness \\
\hline AS3 & Possible overkill (IV) & M & Fitness \\
\hline AS4 & Possible overkill (IV) & M & Fitness \\
\hline AI4 & Keep up the good work (I) & I & Elimination \\
\hline AI5 & Low priority (III) & I & Elimination \\
\hline AS5 & Possible overkill (IV) & I & Elimination \\
\hline & & & \\
\hline
\end{tabular}

jelas mengenai penggunaan), AS6 (Mengerti akan kebutuhan pengguna).

Kategori keempat yang berada pada kategori must be adalah fitness. Ada 3 atribut masuk kategori ini, yaitu: AS2 (Perhatian kepada para pengguna perpustakaan), AS3 (Ramah dan sopan dalam melayani), dan AS4 (Cepat, tanggap dan berinisiatif membantu pengguna yang memerlukan bantuan). Atribut dalam kategori ini memiliki performansi yang tinggi, walaupun tingkat kepentingannya rendah. Strategi yang dapat diterapkan adalah tetap dijaga kinerja atribut pelayanannya, walaupun tingakt prioritasnya kedua setelah atribut yang berada pada kategori survival.

Selain keempat kategori yang telah disebutkan, ada satu lagi kategori yang masuk di dalam hasil penelitian, yaitu kategori elimination. Ada 3 atribut yang masuk ke dalam kategori ini yaitu: AI4 (Kelengkapan koleksi: surat kabar), AI5 (Kelengkapan koleksi: digital), AS5 (Punya pemahaman dan ketrampilan yang cukup untuk menjawab pertanyaan dan menyelesaikan masalah yang dihadapi pengguna). Atribut yang masuk ke dalam kategori ini sebaiknya dianalisis lagi keberadaannya, apakah pengguna sudah paham akan fungsi dan kemanfaatan atribut-atribut pelayanan tersebut.

\section{KESIMPULAN}

Dari hasil pengolahan dan analisis diperoleh kesimpulan sebagai berikut: Tingkat kepuasan pengguna perpustakaan secara umum mencapai 3,59 dengan skala 5 sehingga kualitas perpustakaan masih harus terus ditingkatkan. Terdapat 9 atribut pelayanan yang berada dalam kuadran pertama IPA, yaitu: AI4, AI2, LP1,LP2, LP3, LP4, LP5,LP6 danAS1. Atribut pelayanan yang berada pada kuadran II diagram IPA adalah sebagai berikut: AI1, AI3,AI8, PC3. Atribut pelayanan pada kuadran III yaitu: AI6, AI7, AI9, AI10, AI11, PC1, PC2, AI5, AS6. Atribut pelayanan yang berada pada kuadran IV yaitu: AS5, AS2, AS3, AS4, AS6. Untuk atribut AS6 berada pada garis batas antara kuadran III dan IV, sehingga bisa masuk ke dalam dua kategori, yaitu low priority maupun possible 
overkill. Dari 26 atribut pelayanan yang diteliti, terdapat 3 atribut pelayanan yang termasuk dalam kategori Indifferent, yaitu atribut (AS5), AI4), dan (AI5). Sedangkan 23 atribut lainnya termasuk dalam kategori Must Be. Menurut IPA-Kano model, atribut pelayanan di perpustakaan USB yang perlu mendapat prioritas utama untuk ditingkatkan yaitu atribut: AI1 (Kelengkapan koleksi buku), AI3 (Kelengkapan koleksi jurnal dan majalah), AI8 (Kemudahan akses internet di perpustakaan), PC3 (Penataan buku di rak yang memudahkan pengguna dalam mencari materi), AI2 (Kelengkapan koleksi karya ilmiah).

\section{DAFTAR PUSTAKA}

[1]. Wu, Hsin-Hung, Yung-Tai Tang dan JyhWei Shyu. 2010, An Integrated Approach of Kano's Model and ImportancePerformance Analysis In Identifying Key Success Factors. African Journal of
Business Management Vol. 4 (15), pp. 3238-3250, Taiwan.

[2]. Sihombing, H., Yuhazri, Yahaya, Yuzrina, M., Azniza, A., 2012, Revisited The Importance and Performance Analysis (IPA) and Kano Model for Customer Satisfaction Measurement, Global Engineers \& Technologists Review, Vol 2(1). pp.22-39 Malaysia.

[3]. Kuo, Y.. -F., Chen, J.-Y., and Deng, W.J., 2012, IPA-Kano model: a New Tool for Categorizing and Diagnosing Service Quality Attributes, Total Quality Management and Business Excellence, dx.doi.org/10.1080/14783363.2011. 637811. 